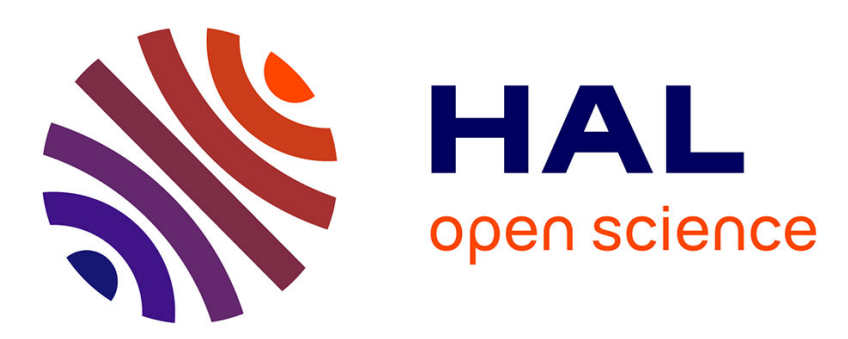

\title{
Sensors for measuring biodegradable and total organic matter in water
}

P. Namour, N. Jaffrezic

\section{To cite this version:}

P. Namour, N. Jaffrezic. Sensors for measuring biodegradable and total organic matter in water. Trends in Analytical Chemistry, 2010, 29 (8), p. 848 - p. 857. 10.1016/j.trac.2010.04.013 . hal00547575

\section{HAL Id: hal-00547575 \\ https://hal.science/hal-00547575}

Submitted on 16 Dec 2010

HAL is a multi-disciplinary open access archive for the deposit and dissemination of scientific research documents, whether they are published or not. The documents may come from teaching and research institutions in France or abroad, or from public or private research centers.
L'archive ouverte pluridisciplinaire HAL, est destinée au dépôt et à la diffusion de documents scientifiques de niveau recherche, publiés ou non, émanant des établissements d'enseignement et de recherche français ou étrangers, des laboratoires publics ou privés. 


\section{Sensors for measuring biodegradable and total organic matter in water}

2 Ph. Namour* ${ }^{1,2}$, N. Jaffrezic-Renault ${ }^{1}$

$3 \quad{ }^{1}$ Université de Lyon, Laboratory of Analytical Sciences, UMR CNRS 5180, 43 boulevard 11

4 novembre 1918, F-69622, Villeurbanne cedex, France

$5 \quad$ 2Cemagref, UR MALY, CP 220, F-69336, Lyon cedex 09, France

6 *Corresponding author, e-mail: philippe.namour@univ-lyon1.fr

7 Abstract: This critical review spans the past two decades and outlines sensors developed for

8 measuring total (TOM) and biodegradable organic matter (BOM) in water. We report the state

9 of the art of the most significant technologies. Although the focus is on in situ devices, we

10 also mention on-line techniques able to lead to sensors sensu stricto and discuss them as

11 possible emerging technologies. We divide the review into sections: (1) TOM; and (2) BOM.

12 We first briefly outline each technique then analyze the published literature. We conclude

13 with recommendations on the technological choices geared to specific research topics.

14 Keywords: biodegradable organic matter, Biochemical Oxygen Demand, Chemical Oxygen

15 Demand, Emerging technology, In situ device, On-line technique, sensor, water, river, BOD, 16 COD.

17 Abbreviations:

ANN: Artificial Neural Network; BDD: Boron Doped Diamond; BOC: Biodegradable

Organic Carbon; BOD: Biochemical Oxygen Demand; COD: Chemical Oxygen Demand;

DOM: Dissolved Organic Matter; DON: Dissolved Organic Nitrogen; MFC: Microbial Fuel

21 Cell; OM: Organic Matter; PCA: Principal Component Analysis; PLS: Partial Least Square

22 (regression method); TOC: Total Organic Carbon; TOM: Total Organic Matter; TON: Total

Organic Nitrogen; WWTP: Wastewater Treatment Plant. 
1 Although 'Organic Matter' $(\mathrm{OM})$ is a term that appears easy to decipher, paradoxically it

2 resists all attempts at formal chemical definition. Thus, since the beginnings of organic

3 chemistry, OM has been defined by its oxidizability, originally by calcination (volatile

4 suspended solid) and then, early in the twentieth century, by wet oxidation methods: chemical

5 oxygen demand $\left(\mathrm{COD}_{\mathrm{Cr}}\right)$ to determine total $\mathrm{OM}(\mathrm{TOM})$ and five-day biochemical oxygen

6 demand $\left(\mathrm{BOD}_{5}\right)$ to determine biodegradable $\mathrm{OM}(\mathrm{BOM})$. The $\mathrm{COD}_{\mathrm{Cr}}$ method uses a two-hour

7 reflux reaction in hot sulfuric acid and two highly toxic ions: $\mathrm{Cr}(\mathrm{VI})$ as oxidant reagent, and

$8 \mathrm{Hg}(\mathrm{II})$ as masking agent camouflaging the interference from the chloride. These two toxic

9 substances condemn this method. Furthermore, running a back titration of the excess dichromate is too insensitive for measuring TOM in river samples [with limit of Detection $(\mathrm{LoD})=30 \mathrm{mg} / \mathrm{L}]$. The $\mathrm{BOD}_{5}$ method is based on aerobic microbial consumption of $\mathrm{BOM}$ at a temperature of $20^{\circ} \mathrm{C}$, in the dark and over an elapsed period of five days. It is cheap, but time-consuming (five-day incubation period) and labor-intensive, requiring skill to get reproducible results. Its precision is around 15\% - 20\%. Moreover, BOM is highly unstable and is partly destroyed during sampling, transport, storage, and test preparation. Even when using a refrigerated sampler, up to $20 \%$ of BOM in raw sewage can be lost within the space of 24 hours. In the second half of the twentieth century, these limitations prompted the development of instrumental methods based on elemental analysis of OM [e.g. total or dissolved organic carbon (TOC or DOC) or nitrogen (TON or DON)]. These analyses do offer alternatives to $\mathrm{COD}$, but unfortunately there is no elemental method for $\mathrm{BOD}_{5}$. The major drawbacks of these methods are acquisition and operation costs, and the need for sampling and sample handling before laboratory analysis.

23 All current conceptual river models focus on daily and seasonal quantitative and qualitative 24 OM variations. The growing focus on the protection, remediation and restoration of aquatic environments has generated an urgent need for advanced monitoring technology, especially in 
1 response to new legislation. However, instrumental techniques cannot affordably deliver the

2 large datasets demanded by these new legislations. The urgent need for continuous, in situ

3 monitoring techniques has driven the search for simple, continuous and in-situ measurement

4 of OM content and time-course evolution. Sensors meet these needs.

5 This article focuses on sensors for TOM (section 2, Table1) and BOM (section 3). Table 2

6 recaps sensors that use Clark electrodes while Table 3 recaps the other techniques. Note that

7 there is confusing overlap in some publications between $\mathrm{COD}_{\mathrm{Cr}}$ and the permanganate method

$8\left(\mathrm{COD}_{\mathrm{Mn}}\right) . \mathrm{COD}_{\mathrm{Mn}}$ has $40-50 \%$ lower oxidation power, and therefore sometimes gives lower

9 results than $\mathrm{BOD}_{5}$. Another source of confusion is the use of various organic compounds as

10 standards, from glucose through to phthalic acid, which skews conclusions on the oxidizing

11 power of the methods proposed.

12 1. Total Organic Matter

\subsection{Photocatalytic Sensors}

These sensors use light to oxidize $\mathrm{OM}$ (Fig. 1). $\mathrm{TiO}_{2}$ is used either alone [1-7] or mixed with other oxides [8, 9]. $\mathrm{ZnO}$ alone gives good results [9]. Photocatalysis presents the low LoDs $(\mathrm{COD}>1 \mathrm{mg} / \mathrm{L})$ needed for river monitoring, with satisfactory reproducibility, but lacks oxidizing power compared to $\mathrm{COD}_{\mathrm{Cr}}$. An Australian team [10] coined the acronym "PECOD" for "photoelectrochemical oxygen demand", a technique based on a photoelectrocatalytic degradation process in a thin-layer photoelectrochemical cell. The method is rapid, at around 2 min for phthalic acid, and concurs well with $\mathrm{COD}_{\mathrm{Cr}}$. Ti $/ \mathrm{TiO}_{2} / \mathrm{PbO}_{2}$ electrodes gives good results compared with $\mathrm{COD}_{\mathrm{Cr}}$, and the relative bias is below $6.0 \%$ [11]. Some authors have compared their results with $\mathrm{COD}_{\mathrm{Mn}}$ values or used readily-oxidizable standards (e.g. glucose or glutamic acid). 
1 Finally, photocatalysis requires close contact between sample and catalyst, and an injection

2 device has to push the sample through these sensors. However photocatalysis has found

3 industrial applications as a pretreatment for toxic industrial wastewater chemical reduction

4 of anthraquinone, phthalocyanide and azo-dyes in effluents from textile factories [4], or

5 degradation of lignin [12] or phenols [9]\}.

\section{1.2. Electrocatalytic Sensors}

7 Electrocatalysis uses electrodes to enhance chemical reactions (Fig. 2). Antimony-doped

8 anode $\mathrm{SnO}_{2}$ [13], $\mathrm{PbO}_{2}$ [14], $\mathrm{Cu} / \mathrm{CuO}[15]$ and $\mathrm{BDD}[14,16]$ give linear relationships with

$9 \mathrm{COD}_{\mathrm{Cr}}$. $\mathrm{AgO}-\mathrm{CuO}$ graphite electrodes give around $80 \%$ of $\mathrm{COD}_{\mathrm{Cr}}$ [17]. The highest oxidation

10 rates have been achieved in presence of hypochlorite electro-generated from chlorides [13].

11 BDD anodes present good stability allied with a wide potential window, and can totally oxide

12 TOM [18] as phenols [14], PAHs [19] or dyestuffs [13, 20], yielding a COD removal rate

13 close to $100 \%$.

14 The drawback is electrode inactivation by metals, requiring cleaning procedures \{e.g.

15 polishing or the application of high-potential anodic polarization [21]\}.

\subsection{Chemiluminescence (CL)}

17 Chemiluminescence (CL) is based on the measure of photons emitted by a chemical reaction. Mn(VII) ions showing CL (at $690 \mathrm{~nm}$ ) when reduced to Mn(II) state are used to determine TOM [22]. The luminol- $\mathrm{H}_{2} \mathrm{O}_{2}-\mathrm{CL}$ reaction is used to amplify $\mathrm{Mn}(\mathrm{II})$ [23], surplus $\mathrm{Mn}(\mathrm{IV})$ [24], or reduced Cr(III) $[25,26]$. The combination of UV-photolysis and CL detection of free-

21 radicals gives results that match to $\mathrm{COD}_{\mathrm{Mn}}$ [27]. The electro-regeneration of $\mathrm{Ru}(\mathrm{bpy})_{3}{ }^{2+}$ suppresses reagent consumption and has been applied successfully to determine oxalate and 23 ethanol [28]. 


\section{$1 \quad$ 1.4. Optical Sensors}

2 The fact that OM exhibits strong absorbance between 200 and $350 \mathrm{~nm}$, and mainly at $254 \mathrm{~nm}$

$3\left(\mathrm{UV}_{254}\right)$, has meant that UV-Visible absorbance is widely used to quantify TOM in water.

4 UV-visible sensors allow multiparametric determinations without reagents, but their

5 applicability remains limited by the properties of the water matrix (turbidity, OM

6 composition, nitrate/nitrite absorbances), and mathematical data reprocessing is required.

7 Spectral deconvolution gives erratic correlations with COD, ranging from $0.57-0.58$ to 0.90

8 [29], even for effluents of the same origin. The fluorescence properties of OM have been also 9 successfully used [30].

\subsection{Commercially available sensors}

Commercially available OM sensors couple UV-scanning with spectral deconvolution. The

Spectro-lyzer (s::scan, Vienna, Austria) gives a good correlation for low COD, although DOC concentrations were not correlated [31]. The manufacturer's calibrations tend to underestimate high concentrations and overestimate low concentrations. These deviations could be reduced after adjustments based on known standards and further improved by specific models integrating the major shifts in the water matrix [32].

Some authors have used an "off-line" calibration algorithm based on PLS-regression [33].

There is also a miniaturized voltammetric sensor comprising five working electrodes (Senset

AB, Linköping, Sweden) [34].

\section{Biodegradable Organic Matter}

\section{2.1. Respirometer}

Respirometry assesses metabolism rates in living organisms by measuring their oxygen consumption. In rivers, oxygen consumption is closely related to microbial activity, which is 
1 itself related to the amount of BOM, so biosensors have been developed based on

2 respirometry to measure the BOM content in water simply in just a few minutes. This

3 principle mirrors $\mathrm{BOD}_{5}$, which is also a respirometric technique. The majority of

4 commercialized BOD equipment measures oxygen through a biofilm (http://www.swift-

5 wfd.com).

\section{$6 \quad$ 2.1.1. Clark Electrode}

7 Microorganisms are entrapped on columns [35] or immobilized on membranes[36-43]. The

8 microorganisms used are pure strains with or without enzymes [36-39], consortia of mixed

9 strains, or inocula from wastewater-treatment plant (WWTPs) [39, 40], synthetic wastewater

10 [41], brackish waters [43] or standardized microbial cultures [42]. Inocula metabolize a

11 broader spectrum of substrates but present a less stable composition and are consequently less

12 constant over time. Furthermore, while dynamic measurements offer a quicker response and a

13 broader detection area, steady-state measurements give reliable results in the concentration

14 range $15-50 \mathrm{mgO}_{2} / \mathrm{L}$ [40]. $\mathrm{BOM}$ can also be monitored in anaerobic processes [44]. Various

15 papers have reported on biofilm optimization [45], immobilization mode [37, 38] and

16 inoculum renewal [41]. Electrolyte consumption and anodic oxidation limit the Clark

17 electrode lifetime, and require the anode surface to be ground of and regular electrolyte

18 renewal to avoid signal drift.

19 Ozonation, or photocatalytic oxidation on $\mathrm{TiO}_{2}$ before passing over a biofilm, gives a variant

20 of chemical bio-sensor or photo-biosensor. However, these hybrid techniques partially attack

21 refractory OM \{e.g., tannic or humic acids, which can be biodegraded up to $51.8 \%$ and

$2238.4 \%$, respectively [39] $\}$, and overestimating BOM introduces confusion between TOM and 23 BOM.

\section{2.1.2. Optical Biosensors}


1 Optical respirometric biosensors measure microbial growth (1) directly from emitting bacteria

2 or (2) indirectly via an oxygen-sensitive colored indicator.

3 Naturally-emissive bacteria such (e.g., Photobacterium phosphoreum) are applied for BOM

4 measurement [46], and the commercially-available toxicity analyzer Microtox employs the

5 emitting strain Vibrio fischeri as test organism. Bioluminescent biosensors can also use

6 genetically-engineered heterotrophic microorganisms, in which the lux genes from $V$. fischeri

7 are integrated to measure microbial growth [47].

8 Another direct optical approach is to measure $\mathrm{NAD}(\mathrm{P}) \mathrm{H}$ (reduced forms of NAD $(\mathrm{P})$ )

9 coenzymes present in all living organisms for redox reactions. While NAD(P)H are

10 fluorescent $(340 / 460 \mathrm{~nm})$, their oxidized counterparts are not. Since NAD(P)H concentrations

11 depend on living cell count and their metabolic activities, the fluorescence intensity from

$12 \mathrm{NAD}(\mathrm{P}) \mathrm{H}$ reflects the amount of BOM [48].

13 In indirect techniques, microorganisms are immobilized on an optical fiber covered with a

14 fluorescent indicator. The presence of oxygen, acting as a quencher, attenuates the

15 fluorescence intensity of the indicator [49-54].

16 These respirometric biosensors give readings within minutes, against the five days required

17 for $\mathrm{BOD}_{5}$. However, the protocol requires sowing and inoculum acclimatization. Moreover,

18 careful maintenance is required when reproducing active consortia, including continuous

19 feeding during prolonged storage. Additionally, fluctuating in-sample oxygen levels cause

20 poor reproducibility unless an oxygen supply is incorporated. The major advantage of optical

21 sensors over the Clark electrode is that they show good long-term stability.

\section{$22 \quad$ 2.2. Microbial fuel cell}

23 The microbial fuel cell (MFC) system converts OM into electricity (Fig. 3). Electron transfer

24 from the microbial cell to the anode occurs either via membrane-associated components 
1 (unmediated biosensors) or via soluble electron shuttles termed mediators (mediated

2 biosensors).

\section{$3 \quad$ 2.2.1. Unmediated electron transfer}

4 Some sulfate-reducing bacteria (e.g., Clostridium sp.) are metal-reducers, able to directly

5 transfer electrons to the anode. Their cytochromes, localized on the outer membrane, can

6 reduce metals. Some species (e.g., Geobacter sp.) have pili (pilus: microbial nanowire) on

7 their outer membrane that are able to transfer their electrons.

8 Activated sludge contains significant amounts of metal-reducing bacteria that can be used as

9 biocatalysts in mediator-less MFC [55-59]. Continuous anaerobic feeding avoids the latency

10 following OM addition and population drift due to starvation, and extends the lifespan of

11 consortium to five years [60]. However, without rigorous maintenance, all MFC are instable

12 and have a limited lifespan.

\subsection{2. $\quad$ Mediated electron transfer}

14 Most strains are electrochemically inactive, which means mediators have to be used to extract 15 electrons from the cell and transfer them to the anode. These mediators are low-molecular-

16 weight redox couples. Hydrophilic mediators \{e.g., potassium hexacyanoferrate(III)

17 (ferricyanide), ruthenium hexamine and ferrocene carboxymethylate are hydrosoluble and cannot cross the cell membrane to enter the cytoplasm, so they are not expected to be able to mediate catabolism in eukaryotic cells. However, lipophilic mediators can cross the cell membrane, enter the cytoplasm, and interact with electron-transport chains. This group

21 includes menadione and benzoamines [61]. Ferricyanide is the most widely used, either alone 22 [62-65] or with menadione [66]. Some natural mediators, including humic acids,

$23 \mathrm{Fe}(\mathrm{II}) / \mathrm{Fe}(\mathrm{III})$, or sulfur/sulfide, are found in activated sludge [67]. 


\section{2.3. Optical sensors}

$2 \mathrm{OM}$ has optical properties that make it possible to use rapid and reagentless techniques

3 requiring little sample preparation. These optical sensors are either "intrinsic" [measuring the

4 optical properties of OM (e.g., UV-visible absorbance)] or "extrinsic" [measuring the optical

5 properties of a suitable oxygen-detecting dye placed on an optical fiber]. Extrinsic sensors

6 were covered under the section on respirometric methods.

\section{$7 \quad$ 2.3.1. $\quad U V$-visible absorption}

8 UV-visible absorption is also used to monitor BOM, but the technique remains relatively

9 inaccurate since refractory structures (e.g. aromatic cycles) exhibit stronger absorption than

10 the BOM (e.g. sugars and fatty acids do not absorb in UV).

11 Association between $\mathrm{BOD}_{5}$ and $\mathrm{UV}_{280}$ decrease across WWTP, from $r^{2}: 0.73$, to $r^{2}: 0.49$ and

$12 r^{2}: 0.11$ in raw influent wastewater, primary effluent, effluent from the nitrification settling 13 basin, respectively [68].

14 The variable relationship between $\mathrm{BOD}_{5}$ and $\mathrm{UV}_{245}$ or $\mathrm{UV}_{280}$ highlighted needs to consider 15 water matrix, as for TOM.

\subsubsection{Fluorimetry}

Some biodegradable compounds are fluorescent, and synchronous fluorescence spectrum has been applied to selected major peaks related to biodegradable and refractory components, in both treated and untreated sewage samples [30,69], in order to differentiate anthropogenic and natural OM or trace groundwater $[70,71]$. This technique shows three different peaks,

21 identified as protein-like (248-280/340-350 nm), fulvic-like, and humic-like peaks. Treated sewage water shows a substantial reduction of the protein-like peak [69], and the fluorescence intensities of the $270 / 350 \mathrm{~nm}$ [71] or 220/350 nm [72] peaks correlate with $\mathrm{BOD}_{5}$. Obviously, 
1 this technique for differentiating anthropogenic from natural $\mathrm{OM}$ is insensitive to nonaromatic

2 pollutants \{e.g., the propylene glycol used as deicer on airplanes [72]\}. Some portable

3 spectrofluorometers using multiple LEDs as excitation sources allow in-field fluorescence

4 analysis [73].

\section{$5 \quad$ 2.4. Tracers or chemical indicators}

6 A tracer is a chemical compound that unambiguously elucidates the source and magnitude of

7 pollution. There is a sharp dichotomy between: (1) animal and bacterial OM (anthropogenic

$8 \mathrm{OM}$ ) of proteinic type and (2) plant OM of lignocellulosic type. It is therefore possible to

9 differentiate natural inputs from residual inputs where the microbial imprint is more

10 pronounced. However, the discrimination is fine-tunable, and compounds are already in use

11 for tracing anthropogenic inputs into the water environment. The organic compounds used as

12 anthropogenic tracers of $\mathrm{OM}$ include sterols and endocrine-disrupting chemicals, detergents

13 and whitening agents \{e.e., linear alkyl benzene sulfonate (LSA: a major household anionic

14 detergent)\}, and caffeine. There are few sensors currently under development that can

15 monitor these tracers.

\subsubsection{Proteins}

17 Proteins are related to microbial activity, and generally speaking, high protein levels are characteristic of allochthonous origins \{e.g., sewer overflows, WWTP discharge or farm waste [74]\}. Proteins can therefore be used as a proxy for BOM quantification, particularly

20 for significant anthropogenic sources. The fluorescence peak of proteinaceous materials at 21 290/350 nm correlated well with BOM [71]. A conductometric biosensor based on protease 22 activities and tested on river and sewer samples showed good relationships with DOC.

23 Modifying its electrode design improves LoDs 2.2-fold [75].

\section{$24 \quad$ 2.4.2. Sterols and phenolic endocrine-disrupting chemicals}


1 Sterol biomarker fingerprinting has been used to trace sewage plumes and identify sewage

2 origins [76, 77]. An enzymatic biosensor associating tyrosinase immobilized on carbon past

3 electrode and amperometric detection was built for the determination of phenolic endocrine-

4 disrupting chemicals (e.g. nonylphenol, a detergent). But unfortunately, no response was

5 registered for nonylphenol (nor for diethylstilbestrol, a synthetic nonsteroidal estrogen) for

6 concentrations lower than $1 \mathrm{mM}$ [78]. Since environmental conditions can influence

7 metabolic processes and overlap the anthropogenic sterols, a useful sensor should ideally give

8 a kind of sterol fingerprint. We can imagine for example a set of sterol cross-reactive sensing

9 elements on microplate and pattern recognition by data processing.

\section{$10 \quad$ 2.4.3. Detergents \& whitening agents}

11 Some sensors have been reported for anionic detergent made up of an immobilized LAS

12 degrading yeast (Trichosporon cutaneum) in a column-reactor type biosensor and an oxygen

13 electrode. This system was able to detect $0.2 \mathrm{mg} / \mathrm{L}$ LAS, but $T$. cutaneum being a

14 heterotrophic yeast, the measure must be corrected of organic matter content [79].

Detergent-selective electrodes comprising an ionophore in PVC membrane and potentiometric detection measured anionic detergents in industrial wastewater. The LoDs for LSA detergents were at $\mu \mathrm{M}$ level [80], and for nonionic detergents [e.g., octylphenol

18 decaethylene glycol ether (Triton X-100) or polyethylene glycol lauryl ether (Brij 35)], were $19 \quad 5.6 \mu \mathrm{M}$ and $33 \mu \mathrm{M}$ respectively. [81].

20 Although cationic detergents seem to interfere strongly on the response of this last sensor, no 21 sensor gives a global measure of the detergent content (anionic, non-ionic and cationic all 22 together). 
1 Recently a fluorescence sensor was proposed for rapid quantification of ionic and non-ionic

2 detergents in solution at sub $\mu \mathrm{M}$ concentrations [82]. Strangely, there is no article about

3 optical sensors to detect fluorescent whitening agents.

\section{$4 \quad$ 2.4.4. Caffeine}

5 Caffeine from beverages and food products is clearly a ubiquitous anthropogenic indicator in

6 domestic wastewater. Caffeine concentrations will depend on regional conditions, and they

7 decrease with increasing efficiency of WWTPs [83].

8 A biosensor based on Pseudomonas alcaligenes and oxygen electrode can detect caffeine over

9 a concentration range 0.1 to $1 \mathrm{~g} / \mathrm{L}$ [84]. But, as all heterotrophic organisms, $P$. alcaligenes

10 also consumes OM present in sample and OM interferes with caffeine measure. A more

11 specific sensor, based on Cytochrome P450 oxidase enzyme system, would be more suitable.

\section{3. Future developments}

13 As environmental parameters present strong coherence due to the dynamic balances inherent 14 in an ecosystem, a structured group of parameters can be exploited to deduce a particular 15 quantity without necessarily measuring it. Also, there is emerging a new global approach, 16 which, avoiding development of a more specific sensor, is centered on mathematical 17 processing of signal from sensor network with the aim of deducing the monitored variable indirectly. This virtual sensor, otherwise known as "soft sensor" or "smart sensor", comprises an array of simple and reliable sensors that are not analyte specific but can be linked by a computer programmed to process certain sample features and build a proxy of the "unsensed"

21 parameter [34]. Virtual sensors will soon measure a 'fingerprint' that can be analyzed by a

22 pattern recognition system. Any sensor can be integrated into a virtual sensor system and its data pooled and processed. 
1 The quality of this approach lies in how the data from the sensor networks is mathematically

2 processed. These processing steps span chemometrics to artificial neural networks (ANNs)

3 and genetic algorithms, and can be clustered under two main objectives:

4 1) to determine structure and data correlations using principal component analysis (PCA)

5 and/or canonical analysis;

6 2) to establish a model from the data that can be used in predictive mode. In this second

7 approach, the techniques used are projections to latent structures and partial least squares

8 (PLS) regression that generalize and fuse the PCA, and the multiple regression methods, or

9 ANNs.

10 Nowadays, the majority of the statistical treatments used bring only qualitative information, 11 and not quantitative. But some results suggest that it might be feasible to use a virtual sensor 12 to monitor OM in drinking water production plants [85], WWTPs [86] or rivers [87].

13 Interestingly, the very same measurement set-up can be used for accurate determinations of 14 TOC, simply by making a few changes to the regression model.

15 A virtual sensor array can also detect changes in the BOM content of wastewater [88]. More recently, a model based on experimental data from five pilot-scale constructed wetland units,

17 used in conjunction with $\mathrm{ANN}$ model, predicted $\mathrm{BOD}_{5}$ removals in horizontal subsurface

18 flow constructed wetlands [86].

In WWTPs, an ANN's model gave reasonable estimates for the $\mathrm{BOD}_{5}$ predicted for a WWTP

20 with average absolute relative errors of $10 \%$ and for a river with a relative standard deviation 21 of $44 \%$ [89].

22 At present, the virtual sensor technology is still under development. But already, and despite 23 the expected difficulties associated with this strongly transdisciplinary approach, some 24 promising results have been obtained. 
1 OM sensors are still in their infancy, and many approaches are being explored. This

2 flourishing research stream offers advantages, since it enables study into OM under different

3 angles. The study objective has to guide the choice of sensor, so, before choosing a technique,

4 the question to ask is what functions are being studied and what is the goal? Functionality can

5 be studied by selecting the most relevant technology.

6 To study BOM, sensors based on respirometry are preferable. They measure oxygen

7 consumption and, more indirectly, the bioavailable OM. However, they remain hampered by

8 reliability issues. The development of new microbial strains coupled with novel techniques

9 (e.g., stabilized enzymes) will help improve the performance of these sensors. Finally, since

10 respirometry sensors have different oxidation strengths, this diversity could be used to

11 discriminate various classes of lability.

12 Spectral methods are specifically adapted to the measurement of aromatic structures that are

13 present in the compounds rather than refractory to their biodegradation (e.g., humic

14 substances). This makes them seemingly better candidates for determining OM origin. Almost

15 all commercialized devices are based on UV-visible spectrometry. However, these sensors

16 require a major calibration effort, and further research needs to be directed towards the

17 automatic selection of the re-calibrations imposed by matrix changes.

18 Virtual sensors are a promising concept, but they are still at the R\&D stage. By deferring the

19 sensor specificity to mathematical processing, this technology leads to a simplification of

20 sensing elements and to a more robust sensor network. It also allows the design of sensor

21 networks specifically tailored to studying individual OM properties.

22 Molecular tracers are useful in studying OM origin, but, as a prerequisite, they need good

23 knowledge of the OM composition. In general, a good tracer associates a narrow specificity to 
1 good stability. Labile compounds (e.g., carbohydrates or proteins) are chemical indicators that

2 are better geared to studying early diagenesis.

3 The sensor technologies that have emerged from environmental sciences in the last couple of

4 decades now require validation. Water quality monitoring is currently based on standardized

5 laboratory methods. Sensors, despite being developed more recently, do not have the same

6 recognition capacities and are only seldom used, despite their advantages. Field validations

7 are needed in order to boost their credibility. ISO standard 15839 (released in 2003) provides

8 a consistent protocol for characterizing these sensors, should facilitate their adoption for

9 routine use by regulatory bodies. Further work is required to increase their operational period, 10 and particularly to prevent bio-fouling and clogging. Other technological challenges include 11 miniaturization of on-chip modules, cutting energy consumption, developing in situ fuelling, 12 eco-design, geolocation, communication checking, and data validation and transmission. It is 13 equally imperative to improve data management. Clearly, there is plenty of room for 14 progression.

\section{References cited}

[1] Kim, Y. C.; Sasaki, S.; Yano, K.; Ikebukuro, K.; Hashimoto, K.; Karube, I., Analytica Chimica Acta, 432 (2001) 59-66.

[2] Chen, J. S.; Zhang, J. D.; Xian, Y. Z.; Ying, X. Y.; Liu, M. C.; Jin, L. T., Water Research, 39 (2005) 1340-1346.

[3] Zhu, L. H.; Chen, Y.; Wu, Y. H.; Li, X. R.; Tang, H. Q., Analytica Chimica Acta, 571 (2006) 242-247.

[4] Harrelkas, F.; Paulo, A.; Alves, M. M.; El Khadir, L.; Zahraa, O.; Pons, M. N.; van der Zee, F. P., Chemosphere, 72 (2008) 1816-1822.

[5] Ai, S. Y.; Li, J. Q.; Ya, Y.; Gao, M. N.; Pan, Z. S.; Jin, L. T., Analytica Chimica Acta, 509 (2004) 237-241.

[6] Lee, K. H.; Kim, Y. C.; Suzuki, H.; Ikebukuro, K.; Hashimoto, K.; Karube, I., Electroanalysis, 12 (2000) 1334-1338.

[7] Li, J. Q.; Li, L. P.; Zheng, L.; Xian, Y. Z.; Jin, L. T., Talanta, 68 (2006) 765-770.

[8] Zhang, Z. H.; Yuan, Y.; Fang, Y. J.; Liang, L. H.; Ding, H. C.; Jin, L. T., Talanta, 73 (2007) 523-528.

[9] Pardeshi, S. K.; Patil, A. B., Solar Energy, 82 (2008) 700-705. 
[10] Zhang, S. Q.; Li, L. H.; Zhao, H. J.; Li, G. Y., Sensors and Actuators B-Chemical, 141 (2009) 634-640.

[11] Li, J. Q.; Zheng, L.; Li, L. P.; Shi, G. Y.; Xian, Y. Z.; Jin, L. T., Talanta, 72 (2007) 1752-1756.

[12] Kansal, S. K.; Singh, M.; Sud, D., Journal of Hazardous Materials, 153 (2008) 412417.

[13] Mao, X. H.; Tian, F.; Gan, F. X.; Lin, A.; Zhang, X. J., Russian Journal of Electrochemistry, 44 (2008) 802-811.

[14] Weiss, E.; Groenen-Serrano, K.; Savall, A., Journal of Applied Electrochemistry, 38 (2008) 329-337.

[15] Silva, C.; Conceição, C. D. C.; Bonifácio, V.; Fatibello, O.; Teixeira, M., Journal of Solid State Electrochemistry 13 (2009) 665-669.

[16] Lee, J.; Park, S. M., Analytica Chimica Acta, 545 (2005) 27-32.

[17] Orozco, J.; Fernandez-Sanchez, C.; Mendoza, E.; Baeza, M.; Cespedes, F.; JimenezJorquera, C., Analytica Chimica Acta, 607 (2008) 176-182.

[18] Martinez-Huitle, C. A.; Ferro, S., Chemical Society Reviews, 35 (2006) 1324-1340.

[19] Wang, B.; Chang, X.; Ma, H. Z., Industrial and Engineering Chemistry Research, 47 (2008) 8478-8483.

[20] Panizza, M.; Cerisola, G., Journal of Hazardous Materials, 153 (2008) 83-88.

[21] Jeong, B. G.; Yoon, S. M.; Choi, C. H.; Kwon, K. K.; Hyun, M. S.; Yi, D. H.; Park, H. S.; Kim, M.; Kim, H. J., Journal of Environmental Monitoring, 9 (2007) 1352-1357.

[22] Fujimori, K.; Takenaka, N.; Bandow, H.; Maeda, Y., Analytical Communications, 35 (1998) 307-308.

[23] Li, B. X.; Zhang, Z. J.; Wang, J.; Xu, C. L., Talanta, 61 (2003) 651-658.

[24] Yao, H.; Wu, B.; Qu, H. B.; Cheng, Y. Y., Analytica Chimica Acta, 633 (2009) 76-80.

[25] Hu, Y. G.; Yang, Z. Y., Talanta, 63 (2004) 521-526.

[26] Liu, W.; Zhang, Z. J.; Zhang, Y. Y., Microchimica Acta, 160 (2008) 141-146.

[27] Su, Y. Y.; Li, X. H.; Chen, H.; Lv, Y.; Hou, X. D., Microchemical Journal, 87 (2007) 56-61.

[28] Lin, J. M.; Qu, F.; Yamada, M., Analytical and Bioanalytical Chemistry, 374 (2002) 1159-1164.

[29] Martins, A. F.; Arsand, D. R.; Brenner, C. B.; Minetto, L., Clean-Soil Air Water, 36 (2008) 875-878.

[30] Lee, S.; Ahn, K. H., Water Science and Technology, 50 (2004) 57-63.

[31] Maribas, A.; da Silva, M. D. L.; Laurent, N.; Loison, B.; Battaglia, P.; Pons, M. N., Water Science and Technology, 57 (2008) 1587-1593.

[32] Rieger, L.; Langergraber, G.; Siegrist, H., Water Science and Technology, 53 (2006) 187-197.

[33] Bertrand-Krajewski, J. L.; Winkler, S.; Saracevic, E.; Torres, A.; Schaar, H., Water Science and Technology, 56 (2007) 17-25.

[34] Winquist, F., Microchimica Acta, 163 (2008) 3-10.

[35] Khan, E.; Babcock, R. W.; Jongskul, S.; Devadason, F. A.; Tuprakay, S., Water Research, 37 (2003) 4981-4991.

[36] Kim, M. N.; Park, K. H., Sensors and Actuators, B: Chemical, 98 (2004) 1-4. 
[37] Kara, S.; Keskinler, B.; Erhan, E., Journal of Chemical Technology and Biotechnology, 84 (2009) 511-518.

[38] Seo, K. S.; Choo, K. H.; Chang, H. N.; Park, J. K., Applied Microbiology and Biotechnology, 83 (2009) 217-223.

[39] Chee, G. J.; Nomura, Y.; Ikebukuro, K.; Karube, I., Biosensors and Bioelectronics, 21 (2005) 67-73.

[40] Velling, S.; Tenno, T., Sensors and Actuators, B: Chemical, 141 (2009) 2336238.

[41] Liu, J.; Olsson, G.; Mattiasson, B., Biosensors and Bioelectronics, 20 (2004) 562-570.

[42] Dhall, P.; Kumar, A.; Joshi, A.; Saxsena, T. K.; Manoharan, A.; Makhijani, S. D.; Kumar, R., Sensors and Actuators, B: Chemical, 133 (2008) 478-483.

[43] Koster, M.; Gliesche, C. G.; Wardenga, R., Applied and Environmental Microbiology, 72 (2006) 7063-7073.

[44] Kumlanghan, A.; Kanatharana, P.; Asawatreratanakul, P.; Mattiasson, B.; Thavarungkul, P., Enzyme and Microbial Technology, 42 (2008) 483-491.

[45] Rastogi, S.; Kumar, A.; Mehra, N. K.; Makhijani, S. D.; Manoharan, A.; Gangal, V.; Kumar, R., Biosensors and Bioelectronics, 18 (2003) 23-29.

[46] Sakaguchi, T.; Morioka, Y.; Yamasaki, M.; Iwanaga, J.; Beppu, K.; Maeda, H.; Morita, Y.; Tamiya, E., Biosensors and Bioelectronics, 22 (2007) 1345-1350.

[47] Sakaguchi, T.; Kitagawa, K.; Ando, T.; Murakami, Y.; Morita, Y.; Yamamura, A.; Yokoyama, K.; Tamiya, E., Biosensors and Bioelectronics, 19 (2003) 115-121.

[48] Huang, L.; Ju, L. K., Water Research, 41 (2007) 1877-1884.

[49] Jiang, Y.; Xiao, L. L.; Zhao, L.; Chen, X.; Wang, X.; Wong, K. Y., Talanta, 70 (2006) 97-103.

[50] Xin, L. L.; Wang, X. D.; Guo, G. M.; Wang, X. R.; Chen, X., Measurement Science and Technology, 18 (2007) 2878-2884.

[51] Lin, L.; Xiao, L. L.; Huang, S.; Zhao, L.; Cui, J. S.; Wang, X. H.; Chen, X., Biosensors and Bioelectronics, 21 (2006) 1703-1709.

[52] Chee, G. J.; Nomura, Y.; Ikebukuro, K.; Karube, I., Biosensors and Bioelectronics, 15 (2000) 371-376.

[53] Dai, Y. J.; Lin, L.; Li, P. W.; Chen, X.; Wang, X. R.; Wong, K. Y., International Journal of Environmental Analytical Chemistry, 84 (2004) 607-617.

[54] Kwok, N. Y.; Dong, S.; Lo, W.; Wong, K. Y., Sensors and Actuators, B: Chemical, 110 (2005) 289-298.

[55] Di Lorenzo, M.; Curtis, T. P.; Head, I. M.; Scott, K., Water Research, 43 (2009) 31453154.

[56] Kim, M.; Youn, S. M.; Shin, S. H.; Jang, J. G.; Han, S. H.; Hyun, M. S.; Gadd, G. M.; Kim, H. J., Journal of Environmental Monitoring, 5 (2003) 640-643.

[57] Chang, I. S.; Jang, J. K.; Gil, G. C.; Kim, M.; Kim, H. J.; Cho, B. W.; Kim, B. H., Biosensors and Bioelectronics, 19 (2004) 607-613.

[58] Moon, H.; Chang, I. S.; Kang, K. H.; Jang, J. K.; Kim, B. H., Biotechnology Letters, 26 (2004) 1717-1721.

[59] Kang, K. H.; Jang, J. K.; Pham, T. H.; Moon, H.; Chang, I. S.; Kim, B. H., Biotechnology Letters, 25 (2003) 1357-1361.

[60] Kim, B. H.; Chang, I. S.; Gil, G. C.; Park, H. S.; Kim, H. J., Biotechnology Letters, 25 (2003) 541-545. 
[61] Chaubey, A.; Malhotra, B. D., Biosensors \& Bioelectronics, 17 (2002) 441-456.

[62] Pasco, N.; Baronian, K.; Jeffries, C.; Webber, J.; Hay, J., Biosensors and Bioelectronics, 20 (2004) 524-532.

[63] Chen, H.; Ye, T.; Qiu, B.; Chen, G.; Chen, X., Analytica Chimica Acta, 612 (2008) 75-82.

[64] Yoshida, N.; Hoashi, J.; Morita, T.; McNiven, S. J.; Nakamura, H.; Karube, I., Journal of Biotechnology, 88 (2001) 269-275.

[65] Trosok, S. P.; Driscoll, B. T.; Luong, J. H. T., Applied Microbiology and Biotechnology, 56 (2001) 550-554.

[66] Nakamura, H.; Suzuki, K.; Ishikuro, H.; Kinoshita, S.; Koizumi, R.; Okuma, S.; Gotoh, M.; Karube, I., Talanta, 72 (2007) 210-216.

[67] Kumlanghan, A.; Liu, J.; Thavarungkul, P.; Kanatharana, P.; Mattiasson, B., Biosensors and Bioelectronics, 22 (2007) 2939-2944.

[68] Nataraja, M.; Qin, Y.; Seagren, E. A., Environmental Technology, 27 (2006) 789-800.

[69] Reynolds, D. M., Journal of Chemical Technology and Biotechnology, 77 (2002) 965972.

[70] Hudson, N.; Baker, A.; Ward, D.; Reynolds, D. M.; Brunsdon, C.; Carliell-Marquet, C.; Browning, S., Science of the Total Environment, 391 (2008) 149-158.

[71] Hur, J.; Hwang, S. J.; Shin, J. K., Water Air and Soil Pollution, 191 (2008) 231-243.

[72] Baker, A.; Inverarity, R., Hydrological Processes, 18 (2004) 2927-2945.

[73] Obeidat, S.; Bai, B.; Rayson, G. D.; Anderson, D. M.; Puscheck, A. D.; Landau, S. Y.; Glasser, T., Applied Spectroscopy 62 (2008) 327-332.

[74] Baker, A., Environmental Science \& Technology, 35 (2001) 948-953.

[75] Khadro, B.; Namour, P.; Bessueille, F.; Leonard, D.; Jaffrezic, N., Journal of Environmental Sciences--CHINA 21 (2009) 545-551.

[76] Jarde, E.; Gruau, G.; Mansuy-Huault, L.; Peu, P.; Martinez, J., Water, Air, and Soil Pollution, 178 (2007) 169-178.

[77] Cordeiro, L. G. S. M.; Carreira, R. S.; Wagener, A. L. R., Organic Geochemistry (2008).

[78] Andreescu, S.; Sadik, O. A., Analytical Chemistry, 76 (2004) 552-560.

[79] Nomura, Y.; Ikebukuro, K.; Yokoyama, K.; Takeuchi, T.; Arikawa, Y.; Ohno, S.; Karube, I., Biosensors and Bioelectronics, 13 (1998) 1047-1053.

[80] Madunic-Cacic, D.; Sak-Bosnar, M.; Samardzic, M.; Grabaric, Z., Sensor Letters, 7 (2009) 50-56.

[81] Sak-Bosnar, M.; Madunic-Cacic, D.; Matesic-Puac, R.; Grabaric, Z., Analytica Chimica Acta, 581 (2007) 355-363.

[82] Härmä, H.; Laakso, S.; Pihlasalo, S.; Hänninen, P., Tenside Surfactants Detergents, 47 (2010) 40-42.

[83] Buerge, I. J.; Poiger, T.; Muller, M. D.; Buser, H. R., Environmental Science and Technology, 40 (2006) 4096-4102.

[84] Babu, V. R. S.; Patra, S.; Karanth, N. G.; Kumar, M. A.; Thakur, M. S., Analytica Chimica Acta, 582 (2007) 329-334.

[85] Krantz-Rülcker, C.; Stenberg, M.; Winquist, F.; Lundström, I., Analytica Chimica Acta, 426 (2001) 217-226. 
[86] Akratos, C. S.; Papaspyros, J. N. E.; Tsihrintzis, V. A., Chemical Engineering Journal, 143 (2008) 96-110.

[87] Yang, W.; Nan, J.; Sun, D., Journal of Environmental Management, 88 (2008) 318325.

[88] Tønning, E.; Sapelnikova, S.; Christensen, J.; Carlsson, C.; Winther-Nielsen, M.; Dock, E.; Solna, R.; Skladal, P.; Norgaard, L.; Ruzgas, T.; Emneus, J., Biosensors and Bioelectronics, 21 (2005) 608-617.

[89] Dogan, E.; Sengorur, B.; Koklu, R., Journal of Environmental Management, 90 (2009) 1229-1235. 
[Namour P., Jaffrezic N. (2010) Trends in Analytical Chemistry, 29(8) 848-857, doi:10.1016/j.trac.2010.04.013]

Table 1: Methods for TOM determination in water

\begin{tabular}{|c|c|c|c|c|c|c|}
\hline \multirow{2}{*}{ Description } & \multirow{2}{*}{ Application } & Range & LoD & Time & RDS & \multirow{2}{*}{ References } \\
\hline & & $\mathrm{O}_{2} \mathrm{mg} / \mathrm{L}$ & $\mathrm{O}_{2} \mathrm{mg} / \mathrm{L}$ & $\min$ & $\%$ & \\
\hline \multicolumn{7}{|l|}{ Photocatalysis under UV-lamps } \\
\hline Flow system with $\mathrm{TiO}_{2}$ beads, Clark electrode & Lake water & 10 & 0.12 & & 4.4 & [1] \\
\hline Flow system with a $\mathrm{TiO}_{2}$ film electrode, photocurrent measurement & Synthetic wastewater, glucose & 235 & 0.30 & 1 & 1.42 & [2] \\
\hline Fluorinated $\mathrm{TiO}_{2}, \mathrm{Mn}(\mathrm{IV})$ at $525 \mathrm{~nm}$ & Tap and lake water, wastewater (paper industry) & 280 & 0.02 & 10 & 1.1 & [3] \\
\hline $\mathrm{TiO}_{2}$ beads, $\mathrm{Cr}(\mathrm{III})$ at $610 \mathrm{~nm}$ & Food, sewage, chemical wastewater (glucose-spiked) & 100 & nd & 10 & 6.3 & [5] \\
\hline $\mathrm{TiO}_{2}$ beads $\mathrm{O}_{2}$ Clark electrode & Synthetic wastewater, lake water & 7.6 & 0.12 & $3-4$ & 6.8 & [6] \\
\hline $\mathrm{TiO}_{2}$ film, $\mathrm{Cr}(\mathrm{III})$ at $590 \mathrm{~nm}$ & Wastewater (glucose-spiked) & 500 & 20 & 40 & 5 & [7] \\
\hline $\mathrm{ZnO} / \mathrm{TiO}_{2}$ film, $\mathrm{Mn}(\mathrm{IV})$ at $525 \mathrm{~nm}$ & Groundwater & $0.25-10.0$ & 0.1 & 40 & 2.35 & [8] \\
\hline \multicolumn{7}{|l|}{ Electrocatalysis } \\
\hline $\mathrm{TiO}_{2}$ thin-film electrode thin-layer cell & Agri-food, dyes, industrial wastewaters & $100-360$ & $1-0.2$ & $1-5$ & $0.8-1.2$ & {$[10]$} \\
\hline $\mathrm{Ti} / \mathrm{TiO}_{2} / \mathrm{PbO}_{2}$ & Agri-food, industrial wastewaters, dyes & 2500 & 15 & 1 & $7 \%$ & [11] \\
\hline $\mathrm{Cu} / \mathrm{CuO}$ in $0.1 \mathrm{M} \mathrm{NaOH}$ & Soft drinks industry wastewater & 2800 & 20 & 1 & 0.2 & {$[15]$} \\
\hline $\mathrm{BDD}$ in $1 \mathrm{M} \mathrm{NaOH}$ & Glucose & 1900 & 95 & 1 & 6 & [16] \\
\hline $\mathrm{AgO}-\mathrm{CuO}$ in graphite polystyrene anodes in $0.1 \mathrm{M} \mathrm{NaOH}$ & Glucose solution, winemaking wastewater & 1400 & 5 & 1 & 8.5 & {$[17]$} \\
\hline $\mathrm{Cu}$, with a grinding device cleaning its surface, in $0.1 \mathrm{M} \mathrm{NaOH}$ & Glucose solution, wastewater $\left(1^{\text {st }}\right.$ sedimentation tank $)$ & 1000 & 10 & 10 & nd & {$[21]$} \\
\hline \multicolumn{7}{|l|}{ Chemiluminescence } \\
\hline Flow system measuring $\mathrm{Mn}$ (II) concentrated on-column & Lake waters & 4000 & 4 & 1.5 & 4.4 & {$[23]$} \\
\hline Microplate reader measuring $\mathrm{Mn}(\mathrm{IV})$ at $640 \mathrm{~nm}$ & Natural waters, drug wastewater & 19 & 0.1 & $<1$ & 4 & {$[24]$} \\
\hline Photodiode detects $\mathrm{Cr}(\mathrm{III})$ & Dyes, garbage leakage, wastewaters & 700 & 2 & nd & 4.5 & [25] \\
\hline Flow system measuring $\mathrm{Cr}(\mathrm{III})$ & Wastewaters & 10000 & 100 & nd & 2.7 & [26] \\
\hline A flow injection system integrating UV photolysis & Certified freshwaters, lake waters & 20 & 0.08 & 10 & 2.7 & [27] \\
\hline
\end{tabular}


[Namour P., Jaffrezic N. (2010) Trends in Analytical Chemistry, 29(8) 848-857, doi:10.1016/j.trac.2010.04.013]

Table 2: Sensors for BOM using a Clark electrode

\begin{tabular}{|c|c|c|c|c|c|c|}
\hline \multirow[b]{2}{*}{ Description } & \multirow{2}{*}{ Applications } & Range & LoD & Time & RDS & \multirow{2}{*}{ References } \\
\hline & & $\mathrm{O}_{2} \mathrm{mg} / \mathrm{L}$ & $\mathrm{O}_{2} \mathrm{mg} / \mathrm{L}$ & $\min$ & $\%$ & \\
\hline WWTP consortium on beads in-column & Tap water, diluted wastewaters & 12 & 0.15 & $>180$ & $5.7-22.6$ & {$[35]$} \\
\hline Klebsiella sp. from activated sludge and enzymes immobilized on membrane & Monosaccharides & nd & nd & 30 & nd & {$[36]$} \\
\hline P. syringae in highly porous micro-cellular polymer & Glucose-glutamic acid & 100 & 3.3 & $3-5$ & 3 & {$[37]$} \\
\hline Encapsulated $S$. cerevisiae on calcium alginate & Glucose-glutamic acid & 40 & nd & 3 & & {$[38]$} \\
\hline Flow system combining photocatalysis on $\mathrm{TiO}_{2}$ and passage on $P$. putida & River waters & 8 & 1 & $5-10$ & 12 & {$[39]$} \\
\hline WWTP consortium & OECD synthetic wastewater & 230 & 15 & $1.5-2$ & 7.5 & {$[40]$} \\
\hline Consortium from synthetic wastewater in flow cell & Synthetic wastewaters & 700 & 5 & 60 & 7.3 & {$[41]$} \\
\hline Reference consortium (DONSEED) on nylon membrane & Brewery wastewaters & 90 & 1 & 15 & 4 & {$[42]$} \\
\hline $\begin{array}{l}\text { Bacteria from brackish waters on polyurethane membrane, fixed on a Clark electrode or } \\
\text { optical fibre }\end{array}$ & Monosaccharides, disaccharides & $1.9-96$ & 1.9 & $15-120$ & 10 & [43] \\
\hline WWTP consortium & Food, tannery, paper industry wastewaters & 60 & 1 & $5-7$ & $5 \%$ & {$[45]$} \\
\hline Ph. phosphoreum on a bio-chip, measured by digital camera & Domestic, industrial wastewaters & 16 & 1 & 20 & 3 & [46] \\
\hline Recombinant $E$. coli containing lux genes from $V$. fischeri & Domestic, industrial wastewaters & 200 & 3 & $60-120$ & 14.2 & {$[47]$} \\
\hline
\end{tabular}


[Namour P., Jaffrezic N. (2010) Trends in Analytical Chemistry, 29(8) 848-857, doi:10.1016/j.trac.2010.04.013]

Table 3: Biosensors for BOM without a Clark electrode

\begin{tabular}{|c|c|c|c|c|c|c|}
\hline \multirow{2}{*}{ Description } & \multirow{2}{*}{ Applications } & Range & LoD & Time & RDS & \multirow{2}{*}{ References } \\
\hline & & $\mathrm{O}_{2} \mathrm{mg} / \mathrm{L}$ & $\mathrm{O}_{2} \mathrm{mg} / \mathrm{L}$ & $\min$ & $\%$ & \\
\hline Marine microorganisms on silicate film with Ru(II) & Seawater & 40 & 0.1 & 3 & 3 & [49] \\
\hline Marine strains on silicate film with a $\mathrm{Ru}$ (II) & Seawater & 40 & 0.18 & 20 & 3.6 & [50] \\
\hline Microorganisms on silicate film with $\mathrm{Ru}(\mathrm{II})$ & Seawater & 40 & 0.2 & 13 & 1.2 & [51] \\
\hline P. fluorescens on nylon membrane onto optical fibre & Synthetic wastewaters & 10 & 0.5 & 15 & 20 & [52] \\
\hline Microorganisms in polymer and $\mathrm{Ru}(\mathrm{II})$ & Seawater & 200 & 4 & nd & 4 & [53] \\
\hline B. subtilus and consortium from activated sludge, fluorimetry on $\mathrm{Ru}(\mathrm{II})$, & Domestic wastewaters & 60 & nd & 50 & 18 & [54] \\
\hline $\begin{array}{l}\text { Single-chamber MFC with an air cathode, consortium from WWTP } \\
\end{array}$ & Artificial and diluted wastewaters & 350 & 50 & 60 & 0.5 & [55] \\
\hline On-line MFC WWTP inoculum & Wastewaters & 150 & 10 & 45 & 1.6 & [56] \\
\hline Flow MFC WWTP inoculum feed with wastewater & Synthetic wastewater & 100 & nd & 60 & 10 & [57] \\
\hline Flow MFC WWTP inoculum feed with synthetic wastewater & Synthetic wastewater & 100 & 20 & 5 & nd & [58] \\
\hline Flow MFC oligotrophic inoculum feed with river water & Surface water \& synthetic wastewater & nd & nd & nd & nd & [59] \\
\hline P. vulgaris on polyvinyl acetate, (ferricyanide) & Wastewaters & $19-150$ & 4.8 & 60 & nd & [62] \\
\hline Marine microorganisms on a functionalized glassy carbon electrode (ferricyanide) & GGA standard solution, seawater & 40 & 1.2 & 30 & 7.7 & [63] \\
\hline P. fluorescens on cellulose acetate membrane, (ferricyanide) & Wastewaters & 260 & 5 & 20 & 10.5 & [64] \\
\hline Yeasts from pulp mill effluent on glassy carbon electrodes (ferricyanide) & Pulp mill effluents & 100 & 2 & 5 & 10 & [65] \\
\hline S. cerevisiae and double mediator system (ferricyanide \& menadione) & Synthetic water & 220 & 6.6 & 15 & 9.1 & [66] \\
\hline MFC feed with anaerobic sludge from biogas reactor & Glucose & 25,000 & 25 & $3-5$ & 7.2 & [67] \\
\hline
\end{tabular}




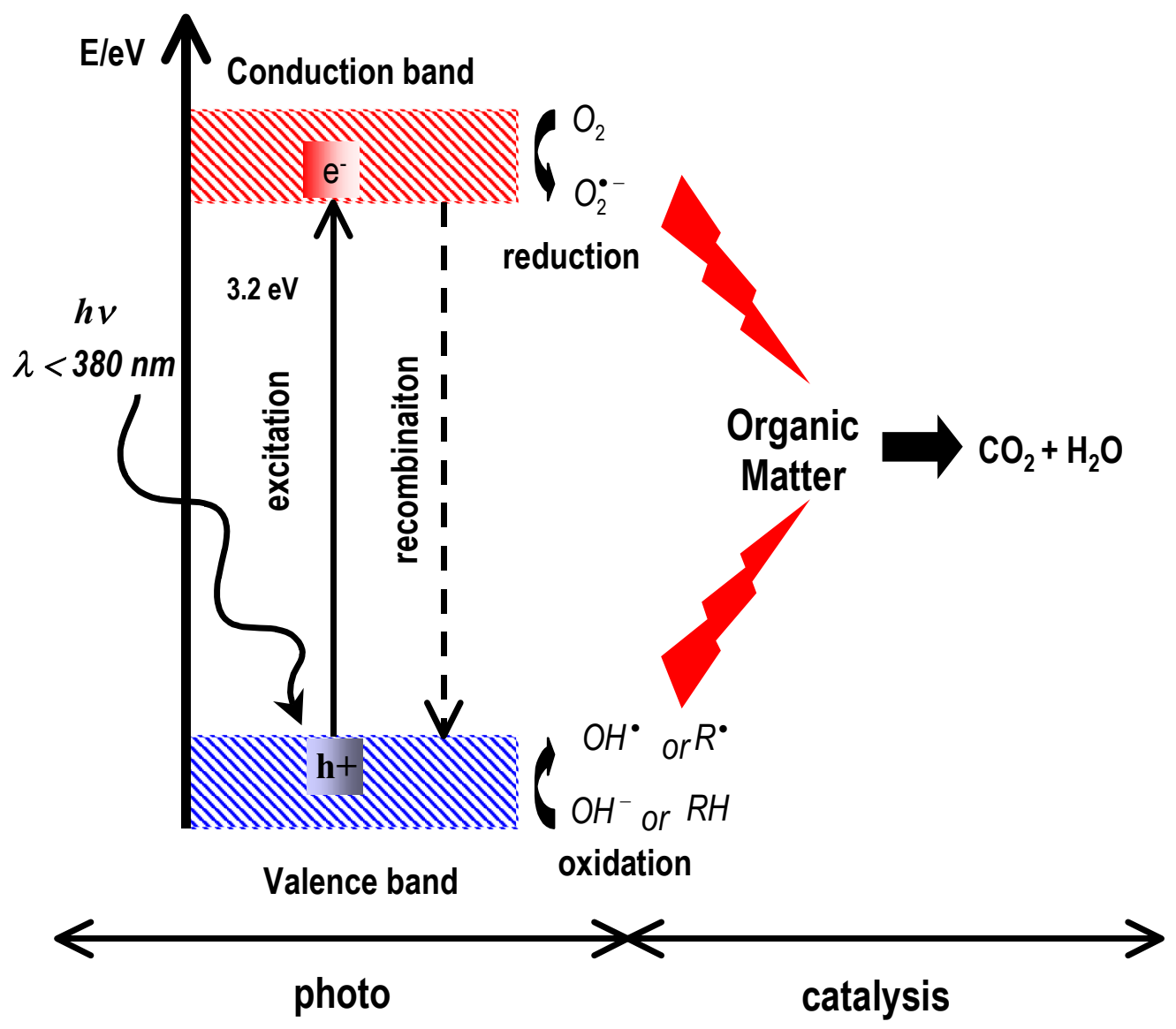

Figure 1: Photocatalytic mechanism on a semiconductor surface illuminated with energy $>3.1 \mathrm{eV}(380 \mathrm{~nm})$. An electron jumps from the valence band to the conduction band, leaving a positive hole. This electron can be transferred to oxygen (or $\mathrm{H}+$; chlorinated compounds), initiating various reactions. The hole can produce hydroxyl radical (or, with water: organic compounds). Free-radicals are strong oxidants, able to mineralize OM. 


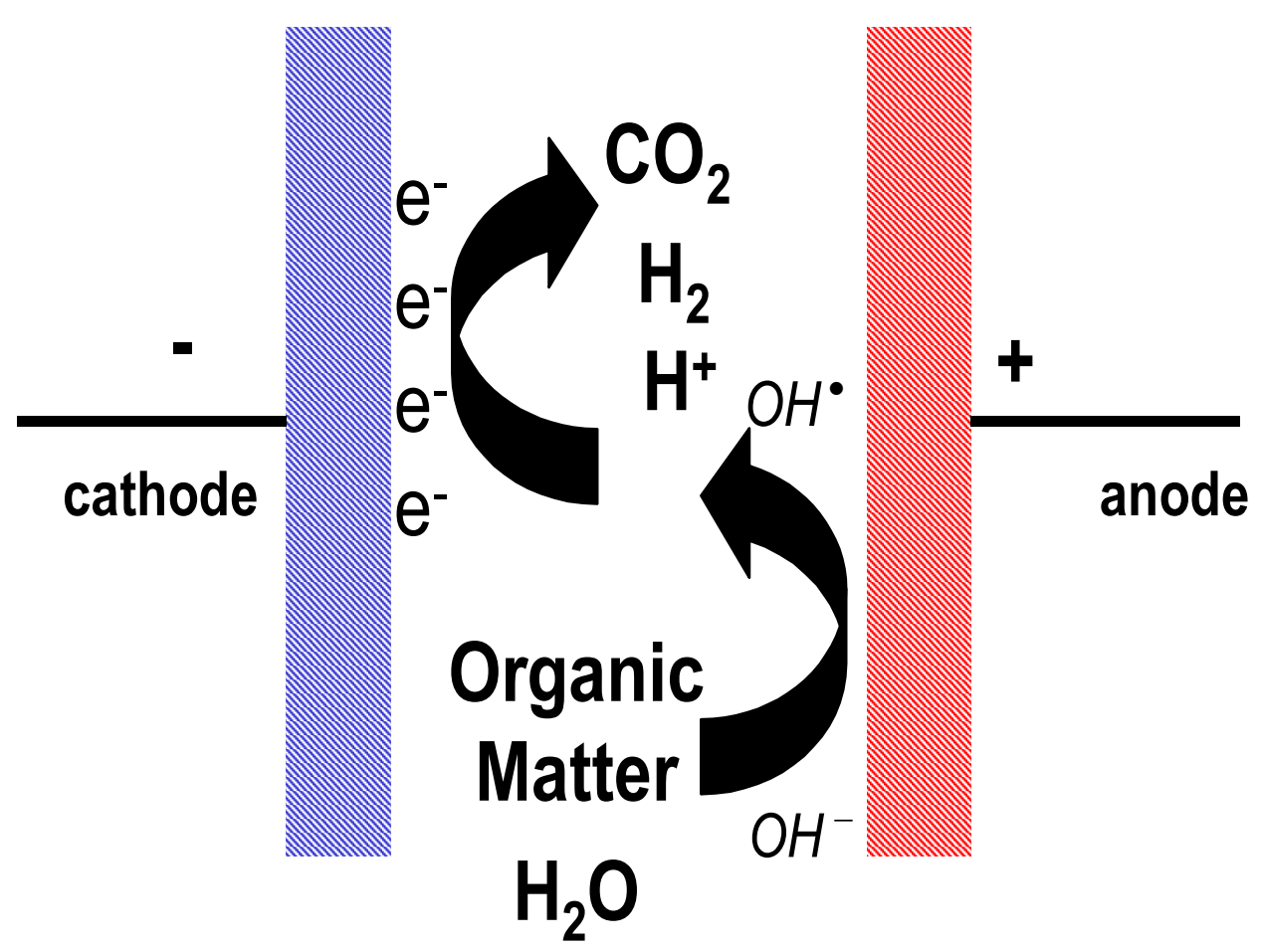

Figure 2: The principle of electrocatalysis is based on a powerful oxidizing activity generated at the electrode surface. The electrons released during oxidation can be measured as an electrical current proportional to the quantity of OM oxidized. 


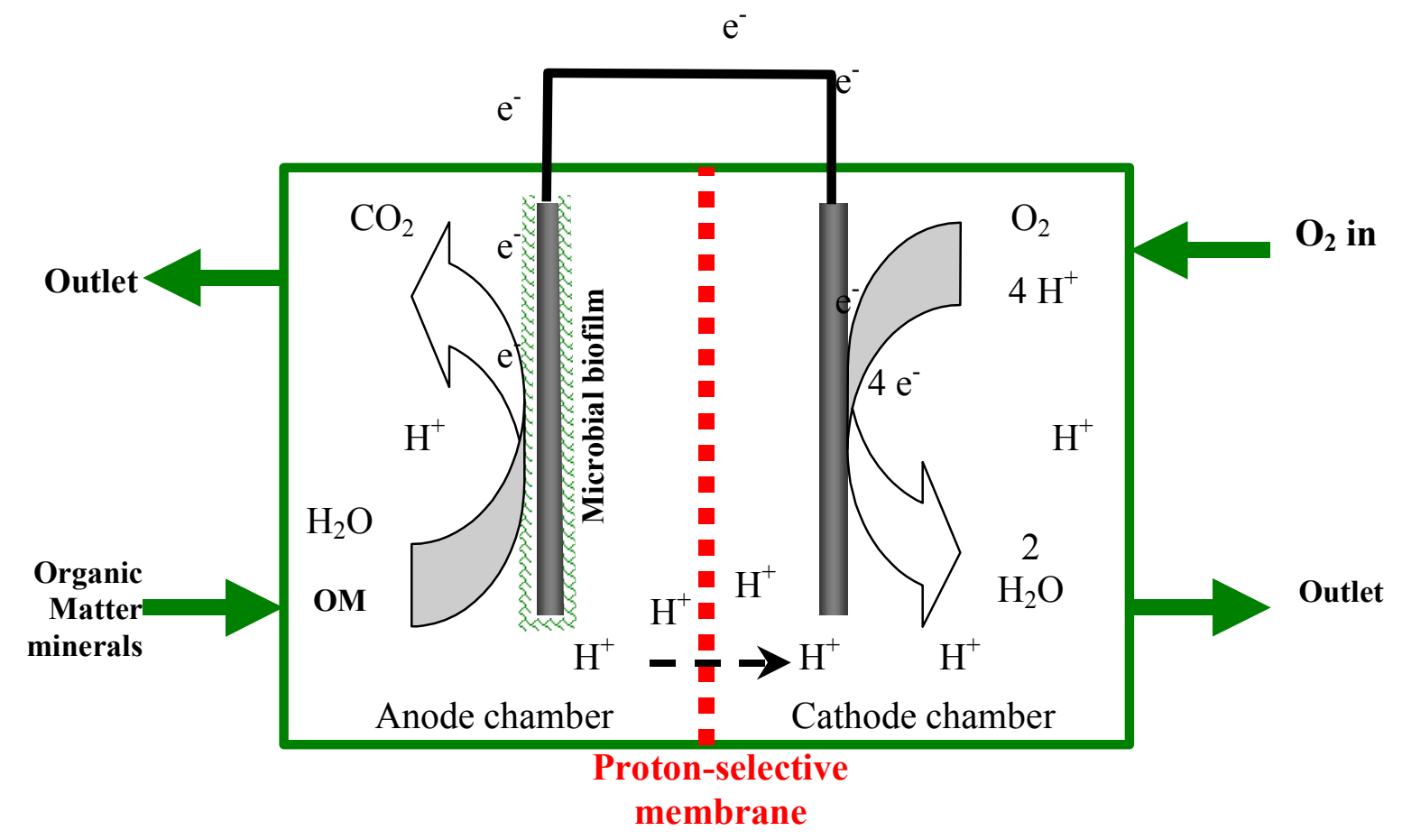

Figure 3: A microbial fuel cell consists of an anaerobic chamber with an anode, and an aerobic chamber with a cathode, the two separated by a proton-exchange membrane. In the anaerobic chamber, the anode short-circuits the natural electron acceptors, such as oxygen or nitrate. The protons then pass through the proton-selective membrane toward the aerobic chamber. The electrons produced are transferred to the cathode, where they reduce oxygen to form water. 